\title{
Methods for Producing and Practical Use of Synthesis Gas (Review)
}

\author{
Andrey V. Zhuikov* and Anatoly I. Matiushenko \\ Siberian Federal University \\ Krasnoyarsk, Russian Federation
}

Received 01.04.2020, received in revised form 03.04.2020, accepted 09.04.2020

\begin{abstract}
The article details the process of gasification of fuel, which takes place inside the gas generator during synthesis gas production, gives examples of industrial application of synthesis gas obtained from coal both in Russia and abroad. Various types of gas generators are described. The calorific characteristics of synthesis gases obtained from different fuels and different methods were analyzed. What is described is a combined cycle of complex gasification of BIGCC biomass with the given example of exergetic analysis. The topic of calorie content of synthesis gas obtained during thermal depolymerization of organic fuel in the absence of oxygen is covered.
\end{abstract}

Keywords: gasification, syngas, pyrolysis, thermochemical conversion, BIGCC, exergy, exergetic analysis.

\section{Способы получения и практического применения синтез-газа (обзор)}

\author{
А.В. Жуйков, А.И. Матюшенко \\ Сибирский федеральнылй университет \\ Российская Федераџия, Красноярск
}

Аннотация. В статье подробно рассмотрен процесс газификации топлива, протекающий внутри газогенератора при получении синтез-газа, приведены примеры промышленного применения синтез-газа, полученного из углей, как в России, так и за рубежом. Описаны различные виды газогенераторов. Проанализированы теплотворные характеристики синтез-газов, полученных из различных видов топлива и различными способами. Описан

(C) Siberian Federal University. All rights reserved

This work is licensed under a Creative Commons Attribution-Non Commercial 4.0 International License (CC BY-NC 4.0).

* Corresponding author E-mail address: azhuikov@sfu-kras.ru 
комбинированный цикл комплексной газификации биомассы BIGCC с приведенным примером эксергетического анализа. Освещена тема калорийности синтез-газа, полученного при термической деполимеризации органического топлива в отсутствие кислорода.

Ключевые слова: газификация, синтез-газ, пиролиз, термохимическая конверсия, BIGCC, эксергия, эксергетический анализ.

Цитирование: Жуйков, А.В. Способы получения и практического применения синтез-газа (обзор) / А.В. Жуйков, А.И. Матюшенко // Журн. Сиб. федер. ун-та. Техника и технологии, 2020. 13(4). С. 383-405. DOI: 10.17516/1999-494X-0232

\section{Введение}

Одной из основ мировой экологической проблемы является глобальное потепление, возникающее из-за выбросов парниковых газов в результате производства тепловой и электрической энергии. Спрос на электрическую энергию растет с развитием мировой индустрии. Для ее выработки в основном используется ископаемое топливо, которое приводит к выбросам углекислого газа, доля которого от всех парниковых газов, влияющих на глобальное потепление, составляет $76 \%$. Согласно прогнозам, к концу XXI века средняя температура планеты увеличится на $1,8-5,8^{\circ} \mathrm{C}[1]$. Сжигание твердого топлива как метод получения тепловой и электрической энергии начинает устаревать, и модернизация его крайне тяжела в отсутствие перспектив. Ученые со всего мира пытаются решить следующие задачи для получения тепловой и электрической энергии при сжигании твердого топлива: снижение парникового эффекта, снижение вредных выбросов оксидов азота, оксидов серы и других веществ; влияние на экологическую ситуацию и глобальное изменение климата, и многие другие. Одним из решений использования твердого топлива может служить его термохимическая подготовка и получение из него экологически чистых видов топлива.

К термохимическим методам относят сжигание, полную газификацию, полукоксование, быстрый пиролиз, медленный пиролиз, мгновенный пиролиз и другие. Выбор метода зависит от характеристик топлива, которое необходимо получить в результате термохимической конверсии. Продуктивный рывок в исследованиях термохимической обработки твердого топлива советские ученые сделали в годы Второй мировой войны, так как основной сырьевой базой для получения моторных топлив и смазочных масел стали все виды твердого топлива. Академик Н.Н. Некрасов выпустил ряд работ, посвященных заменителям нефтепродуктов, полученных при помощи газификации ископаемого топлива [2]. В табл. 1 и 2 представлена часть его результатов, из которых видно, что все основные нефтяные продукты можно получить при помощи термохимической конверсии из бурых и каменных углей. Добыча открытым способом бурого угля марки Б2, Б3 в Красноярском крае составляет более 70 \% от общероссийского.

Рассмотрим предметно получение одного из продуктов термохимической обработки - синтез-газа. Синтез-газ предназначен для получения тепловой, электрической энергии или для промышленно-химических процессов. Получение синтез-газа из топлива можно описать как термохимическую конверсию, протекающую при интеграции кусков топлива с окислителем (рис. 1), в виде кислорода, пара, технического кислорода, смеси водяного пара и кислорода и др. с целью превращения его в горючий газ $\left(\mathrm{CO}, \mathrm{CO}_{2}, \mathrm{H}_{2}, \mathrm{CH}_{4}\right)$. Термохимический процесс получения синтез-газа из топлива проходит в устройствах с разными конструктивными особенностями, 
Таблица 1. Продукты, получаемые из бурого угля

Table 1. Products derived from brown coal

\begin{tabular}{|l|l|l|}
\hline \multicolumn{1}{|c|}{ Заменители нефти } & \multicolumn{1}{|c|}{$\begin{array}{c}\text { Методы термохимической } \\
\text { переработки }\end{array}$} & \multicolumn{1}{|c|}{ Основная товарная продукция } \\
\hline Бурый уголь & a) Газификация & a) Генераторный или водяной газ \\
\hline Бурый уголь & b) Синтез газов & $\begin{array}{l}\text { b) Бензин } \\
\text { b) Дизельное топливо } \\
\text { b) Смазочные масла } \\
\text { b) Сжиженные газы } \\
\text { b) Парафин }\end{array}$ \\
\hline Бурый уголь & c) Полукоксование & $\begin{array}{l}\text { c) Бензин } \\
\text { c) Керосин } \\
\text { c) Мазут } \\
\text { c) Фенолы } \\
\text { c) Полукокс }\end{array}$ \\
\hline Бурый уголь & & d) Монтан-воск \\
\hline
\end{tabular}

Таблица 2. Продукты, получаемые из каменных углей

Table 2. Products derived from coal

\begin{tabular}{|c|c|c|}
\hline Топливо & $\begin{array}{c}\text { Методы термохимической } \\
\text { переработки }\end{array}$ & Продукты, получаемые из угля \\
\hline Каменный уголь & а) Гидрирование & $\begin{array}{l}\text { a) Бензин } \\
\text { a) Сжиженные газы }\end{array}$ \\
\hline Каменный уголь & $\begin{array}{l}\text { b) Газификация (включая } \\
\text { подземную газификацию) }\end{array}$ & $\begin{array}{l}\text { b) Генераторный или водяной газ } \\
\text { b) Генераторная смола }\end{array}$ \\
\hline Каменный уголь & $\begin{array}{l}\text { c) Синтез газов (окиси углерода } \\
\text { и водорода) }\end{array}$ & $\begin{array}{l}\text { c) Бензин } \\
\text { c) Дизельное топливо } \\
\text { c) Смазочные масла } \\
\text { c) Сжиженные газы }\end{array}$ \\
\hline Каменный уголь & d) Полукоксование & $\begin{array}{l}\text { d) Парафин } \\
\text { d) Полукокс } \\
\text { d) Бензин } \\
\text { d) Керосин } \\
\text { d) Мазут } \\
\text { d) Фенолы }\end{array}$ \\
\hline
\end{tabular}

называемых газогенераторами (рис. 1). Газогенераторы делятся на одноступенчатые и многоступенчатые. Многоступенчатые газогенераторы, в свою очередь, делятся на: газогенераторы с плотным слоем, с кипящим слоем и на поточные газогенераторы. Газогенераторы с плотным слоем бывают: прямоточные, противоточные, горизонтального процесса и комбинированного процесса. Газогенераторы с кипящим слоем разделяются на: со стационарным кипящим слоем, с внешней или внутренней рециркуляцией, с двумя реакционными камерами [3-10].

Синтез-газ выходит через газоотводящий патрубок, расположенный в верхней части устройства. Основа технологии получения горючего газа включает в себя процесс неполного окисления топлива при дефиците кислорода либо неполное сгорание с последующим взаимо-

$$
-385-
$$




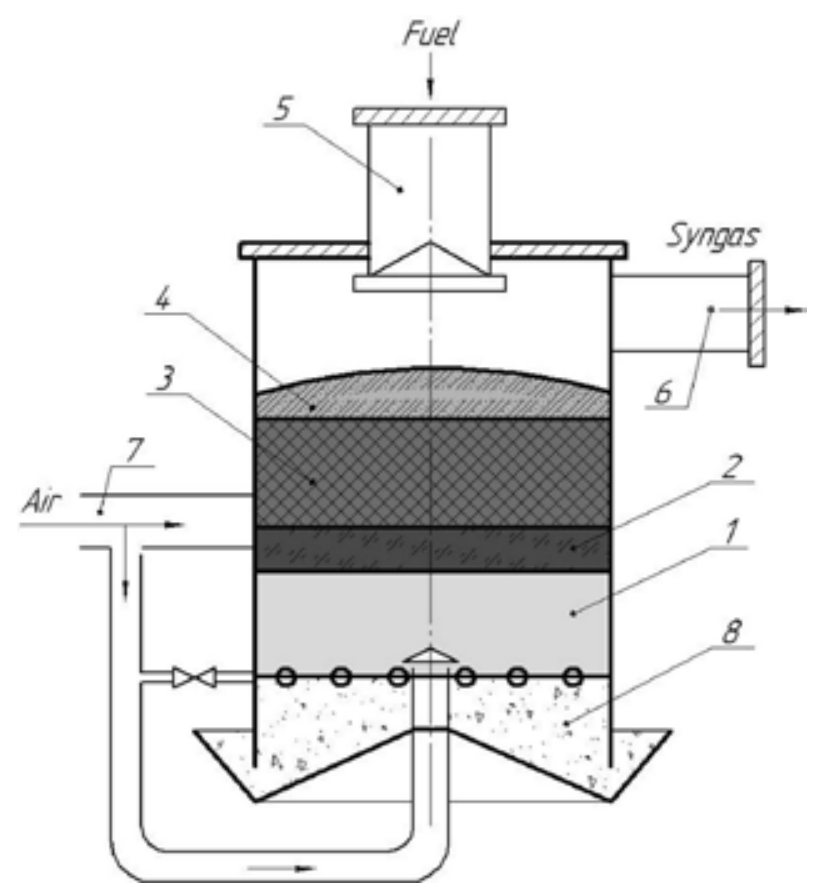

Рис. 1. Газогенератор (1 - зона частичного окисления; 2 - зона восстановления; 3 - перолитическая зона; 4 - зона подготовки-сушки топлива; 5 - система загрузки топлива; 6 - выход генераторного газа; 7 - подвод дутья; 8 - золошлаковые продукты)

Fig. 1. Gasifier (1 - partial oxidation zone; 2 - recovery zone; 3 is a semi-coking zone; 4 - fuel preparation-drying zone; 5 - fuel loading system; 6 - generator gas outlet; 7 - blow supply; 8 - ash-slag dresser)

действием углерода с двуокисью углерода и водяным паром. Реакции восстановления имеют эндотермические свойства, т.е. сопровождаются поглощением тепла [11-15].

Газифицируемый материал загружается в газогенератор через систему загрузки топлива, подвергаясь сушке для удаления лишней влаги. Затем сухое условное топливо начинает термическое разложение в потоке горячего газа, двигающегося от золошлакового комода к горловине газогенератора, где происходит его коксование вследствие сложного видоизменения его внутренней структуры.

В зоне частичного окисления, расположенной над золошлаковым комодом, происходит сгорание топлива, описанное следующими термохимическими реакциями:

$$
\begin{aligned}
& \mathrm{C}+\mathrm{O}_{2}+3,76 \mathrm{~N}_{2}=\mathrm{CO}_{2}+3,76 \mathrm{~N}_{2} \\
& 2 \mathrm{C}+\mathrm{O}_{2}+3,76 \mathrm{~N}_{2}=2 \mathrm{CO}+3,76 \mathrm{~N}_{2} .
\end{aligned}
$$

В этой части генератора газа расходуется большая часть кислорода. Соприкасающиеся с решеткой колосника слои золы и шлака играют важную роль засыпки, выравнивающей распределение газов, необходимых для дутьевого процесса, также золошлаковая подушка защищает решетку колосника от перегрева.

Зона горения топлива определяется наличием стационарного процесса окисления, для которого необходимо провести предварительную теплоподготовку (сушку) - подогрев топлива и газов, необходимых для дутьевого процесса, и полная сушка топлива.

$$
-386-
$$


Сушка топлива и газов совершается за счет тепла, поступающего, как правило, из окислительно-восстановительной зоны, описана следующими термохимическими реакциями:

$$
\begin{aligned}
& \mathrm{CO}_{2}+\mathrm{C}=2 \mathrm{CO} \\
& \mathrm{H}_{2} \mathrm{O}+\mathrm{C}=\mathrm{CO}+\mathrm{H}_{2} ; \\
& 2 \mathrm{H}_{2} \mathrm{O}+\mathrm{C}=\mathrm{CO}_{2}+2 \mathrm{H}_{2} ;
\end{aligned}
$$

а в некоторых случаях и извне. Поступающее топливо в окислительно-восстановительную зону сопровождается его воспламенением, т.е. резким увеличением температуры за счет стремительно нарастающего выделения тепла из-за возрастания скорости экзотермического процесса.

Исследование получения синтез-газа из твердого топлива при дефиците окислителя, основанное на изучении отечественного и зарубежного опыта последних десятилетий, рассматривает гетерогенную реакцию с участием твердых и газообразных продуктов как химическую реакцию, реализующуюся на поверхности кусков топлива [16-22].

Образовавшиеся продукты и их объем зависят от реакционной способности кусков топлива, а также от скорости перетекания газообразных молекул к поверхности. Через пограничный слой газовые молекулы проходят к поверхности топлива, а продукты термохимической реакции перетекают с поверхности, поступая в пространство газовой смеси между отдельными кусками. Интенсивность диффузионного потока может зависеть от разных факторов. В случае, если скорость химической интеграции между кусками условного топлива и газовыми смесями высока, то предполагаемый результат соотношения между веществами, вступившими во взаимосвязь, будет зависеть от интенсивности процессов диффузии. В таком случае процесс газификации условного топлива проходит в диффузионной зоне. В случае, если интенсивность химической реакции между условным топливом и смесью газов является решающим фактором, то интеграция между вступившими в химическую взаимосвязь веществами переходит в кинетическую область термохимического процесса.

При возрастании температуры в синтез-газе, увеличении скорости газовых потоков происходит увеличение интенсивности процесса выделения синтез-газа в диффузионной области. При повышении температуры будет увеличиваться интенсивность химического взаимодействия между углеродом полукокса и газовыми молекулами [23-28].

У различных ископаемых топлив и биомасс реакционная способность определяется интенсивностью химического взаимодействия углерода с водяным паром или с двуокисью углерода. Золошлаковые отходы при этом трансформируются и могут забивать собою сопла дутьевых устройств, нарушая процесс получения горючего газа, что приводит к аварийной остановке генератора из-за прекращения дутья. Чтобы предотвратить эти аварийные остановки газификатора к окислителю, подаваемому в систему, подмешивают водяной пар. Применение пара в качестве окислителя обеспечивает некоторое повышение теплотворных способностей газа. Смесь пара с окислителем дает снижение температуры в области газификации до безопасного значения температуры для дутьевых устройств. В качестве присадки к воздушному или кислородному дутью в процессе получения синтез-газа из условного топлива возможно вместо пара применять двуокись углерода.

Практический выход синтез-газа будет значительно ниже теоретического или расчетного. Из этого следует, что для термохимического процесса в ряде случаев можно применять

$$
-387-
$$


окислитель, обедненный свободным кислородом, например дымовой газ, содержащий избыток воздуха [29-31].

Тепло, образовавшееся при газификации топлива, целесообразно расходовать на его сушку, на подогрев дутьевого газа, на получение жидких продуктов пиролиза (bio-oil), на возмещение тепловых потерь при потере от наружного охлаждения и от механической неполноты сгорания. Термохимическое разложение и подсушка условного топлива в генераторе газа отличаются от этих же процессов, но при подводе тепла извне. При термохимической конверсии эти процессы происходят в потоке газовой смеси с высокой температурой, непрерывно проходящей через слои условного топлива. Пиролиз топлива, протекающий в генераторе газа, можно сравнить с разложением его в вакуумной среде, т. е. когда выход жидких продуктов увеличивается. При термохимической конверсии топлива внутри устройства происходит постоянное охлаждение синтез-газа и находящихся в нем жидких и парообразных пиролитических продуктов. Быстрая конденсация высококипящих продуктов пиролиза происходит в синтез-газе, проходящем через преграду в виде условного топлива, интегрирующем в капельно-жидкое состояние с возникновением неоднородного газового вещества. Вследствие этого, в горючем неочищенном газе, выходящем из газогенератора, находятся труднолетучие, термически неустойчивые пиролитические продукты - смолы, которые требуют дополнительной очистки в специальных фильтрах либо при помощи катализаторов.

\section{Газификация топлива. Синтез-газ}

Интерес к генерации синтез-газа в России пропал в 60-х годах XX века из-за масштабного освоения новых месторождений природного газа и нефти. Природный газ и продукты нефтепереработки постепенно вытеснили синтез-газ. И только через несколько десятилетий вновь появился интерес к термообработке низкосортных топлив, примерами являются промышленная установка ЭТХ-175 по комплексной переработке канско-ачинских углей производительностью 1,2 млн тонн угля в год и опытно-промышленная установка для сланцев УТТ-500 на Эстонской ТЭС. Но коммерческого развития эти технологии так и не получили, поэтому были закрыты.

В последнее десятилетие в области исследования термохимической обработки твердых топлив достигнуты высокие результаты, которые успешно внедрены в существующие промышленные объекты. Большой вклад в это развитие внесли В.И. Бабий, Г.С. Асланян, Т.В. Виленский, С.Р. Исламов, С.Г. Степанов, Б.П. Устименко, Б.Н. Кузнецов, А.С. Заворин, П.Н. Кузнецов и другие [32-34].

В настоящее время в России работает ряд промышленных установок, использующих газификацию твердого топлива, одним из них является завод активированных углей ЗАО «Карбоника-Ф» в г. Красноярске по производству активированного угля АБГ и синтез-газа, изображенный на рис. 2 [35]. В качестве топлива использовался бурый уголь Березовского разреза марки Б2. В цехе расположено 20 газогенераторов шахтного типа. Розжиг осуществляется путем включения электротермического устройства, расположенного в верхней части газогенератора. Высота газогенератора составляет 3,5 м, диаметр 2 м, вокруг газогенератора сделана водяная рубашка. В нижней части расположена колосниковая решетка, подвод воздуха и охлаждающего газа. Весь процесс работы газогенератора полностью автоматизирован. По- 


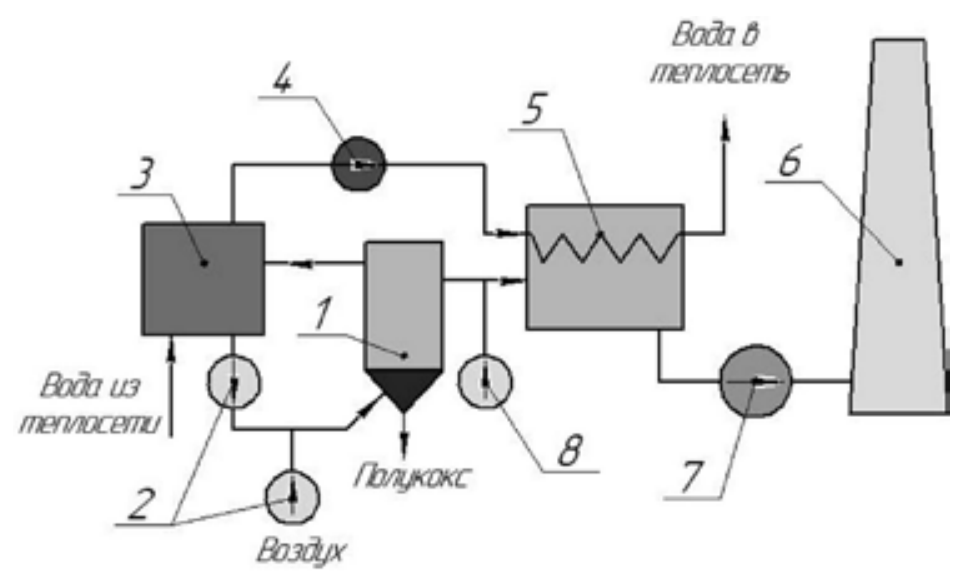

Рис. 2. Технологический процесс на заводе ЗАО «Карбоника-Ф» (1 - газогенератор; 2 - воздуходувки; 3 - кожухотрубный рекуперативный теплообменник; 4 - насос сетевой воды; 5 - водогрейный котелутилизатор; 6 - дымовая труба; 7 - дымосос; 8 - воздуходувка)

Fig. 2. Process at ZAO "Carbonica-F" (1 - gasifier; 2 - blowers; 3 - shell and tube recuperative heat exchanger; 4 - main water pump; 5 - water-heating recovery boiler; 6 - chimney; 7 - smoke exhauster; 8 - blower)

Таблица 3. Состав и теплотворная способность синтез-газа на ЗАО «Карбоника-Ф»

Table 3. Composition and calorific value of synthesis gas at ZAO "Carbonica-F"

\begin{tabular}{|l|c|c|c|c|}
\hline & $\mathrm{H}_{2, \%}$ & $\mathrm{CO}, \%$ & $\mathrm{CH}_{4, \%}$ & $Q, \mathrm{MДж/кг}$ \\
\hline Синтез-газ & 22,2 & 12,2 & 1,6 & 3,45 \\
\hline $\begin{array}{l}\text { Бурый уголь Березовского } \\
\text { разреза }\end{array}$ & - & - & - & 15,91 \\
\hline
\end{tabular}

бочным продуктом является синтез-газ, который сжигают в водогрейном котле, подогревая сетевую воду. Содержание вредных выбросов в уходящих газах по сравнению с сжиганием углей

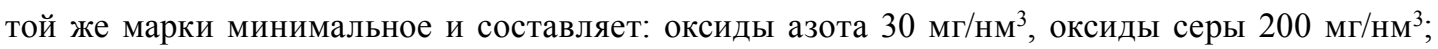
содержание пыли 10 мг/нм³. В табл. 3 представлен состав синтез-газа, далее мы сравним его и с другими подобными газами. Производительность завода составляет до 5 тыс. тонн активированного угля в год. Мощность котельной составляет - 8 Гкал/ч [36].

В поселке Балахта Красноярского края готовится к запуску опытно-промышленная установка (ОПУ), изображенная на рис. 3 , по производству основного продукта - дорогостоящего полукокса, а синтез-газ является второстепенным продуктом. ОПУ включает в себя четыре газогенератора шахтного типа, общей производительностью 4,8 Гкал/ч, рабочее топливо - бурый уголь марки Б3 Балахтинского разреза, состав получаемого газа представлен в табл. 4. Выбор расположения промышленно-опытной установки был сделан специально рядом с Балахтинским разрезом Канско-Ачинского угольного разреза, так как он является ценным в плане термохимической переработки и имеет низкую зольность. В мире всего три подобных угольных разреза: в Казахстане, Индонезии и Колумбии [37].

Синтез-газ сжигают в газовом котле для вспомогательного подогрева сетевой воды, которая поступает по трубопроводу от рядом стоящей отопительной котельной, являющейся ис-

$$
-389-
$$




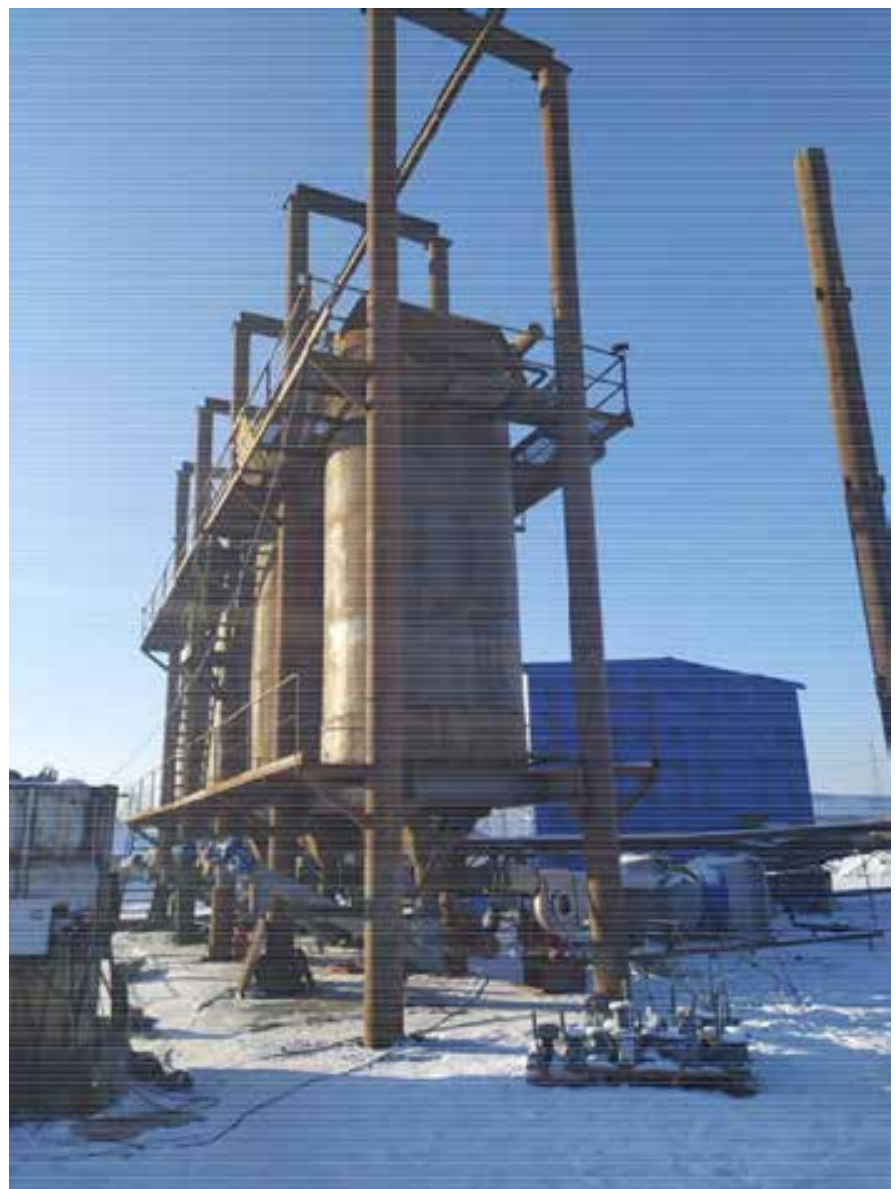

Рис. 3. Опытно-промышленная установка в п. Балахта

Fig. 3. Experimental industrial installation in Balakhta village

Таблица 4. Состав и теплотворная способность синтез-газа из Балахтинского угля

Table 4. Composition and calorific value of synthesis gas from Balakhtin coal

\begin{tabular}{|l|c|c|c|c|}
\hline & $\mathrm{H}_{2}, \%$ & $\mathrm{CO}, \%$ & $\mathrm{CH}_{4}, \%$ & $\mathrm{Q}, \mathrm{MДж/кг}$ \\
\hline Синтез-газ & 6,37 & 23,2 & 1,6 & 4,2 \\
\hline $\begin{array}{l}\text { Бурый уголь Балахтинского } \\
\text { разреза, Б3 }\end{array}$ & - & - & - & 21,42 \\
\hline
\end{tabular}

точником тепловой энергии для поселка. Газогенераторы используют слоевые шахтного типа, растопка происходит в верхней части устройства.

В г. Черногорске Республики Хакасия на промышленном предприятии по производству целлюлозных изделий были переведены на сжигание синтез-газа газо-мазутные паровые котлы ДЕ 6,5*14 ГМО. Пар вырабатывается для бумагоделательных машин. На территории предприятия были установлены 5 слоевых газогенераторов (рис. 4) шахтного типа, работающих на буром угле Б3 Балахтинского разреза. Производительность одного газогенератора - 1,2 Гкал/ч. 


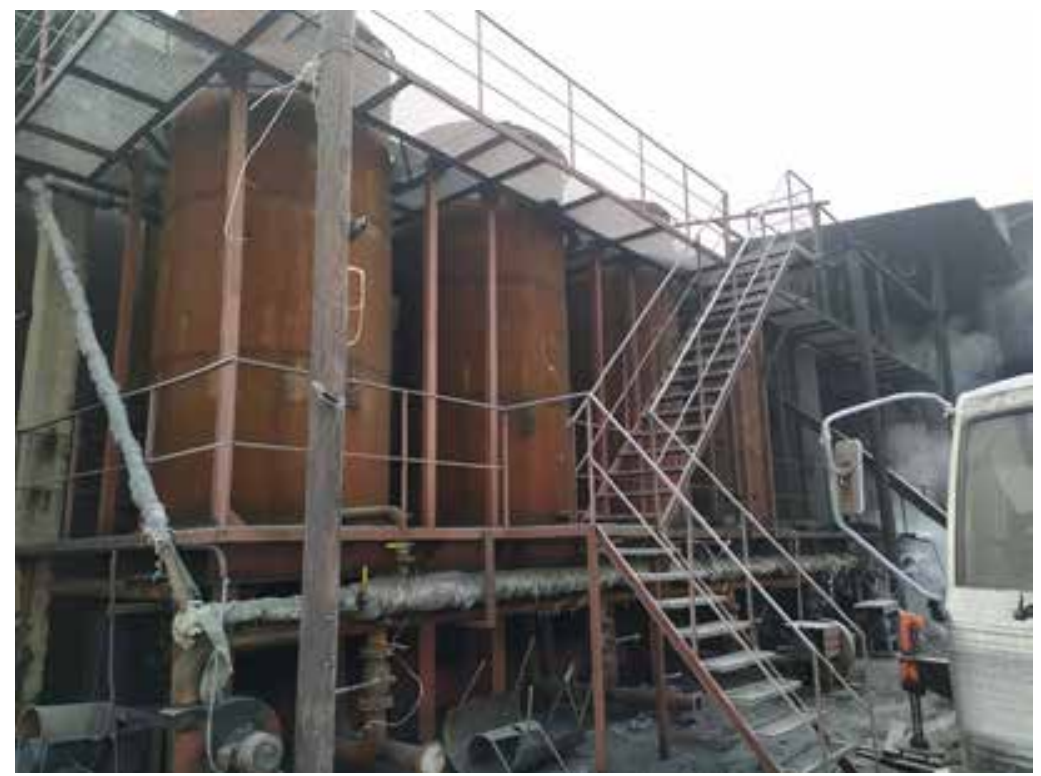

Рис. 4. Газогенераторы в г.Черногорске

Fig. 4. Gasifier in Chernogorsk

Газогенераторы работают до полной выработки газа при высоких температурах, остатком является шлак.

До перевода котлы работали на дорогостоящем мазуте марки М100, который при сжигании выделяет большое количество вредных выбросов. В котельной установлены три котла, два из которых переделаны на газ и находятся постоянно в работе. Мазутный котел стоит в резерве. В планах монтаж еще четырех газогенераторов такого же типа для увеличения мощности предприятия. Все параметры газогенератора выведены на монитор, через который оператор следит за температурой синтез-газа, температурами реактора и многими другими параметрами (рис. 5). Все управление происходит механическим путем.

В Иркутской области на заводе по производству кирпичей «Сибфарфор» на синтез-газ была переведена одна из печей, основным топливом которой до перевода был дорогостоящий мазут. Топливом для двухкамерного газогенератора с кипящим слоем являлся бурый уголь Б2 Ирша-Бородинского разреза КАУбасс с теплотворной способностью 17,5 МДж/м³ , а теплотворная способность синтез-газа достигала до 5 МДж/м³ [38].

\section{Теплотворная способность синтез-газа}

Синтез-газ имеет ряд недостатков по сравнению с другими видами топлива, и один из них - это его низкая теплотворная способность. Теплотворная способность синтез-газа зависит от многих факторов, таких как сам процесс получения газа, типы установок, в какой среде и под каким давлением происходит процесс газификации, вид топлива, из которого получают синтез-газ, и для каких целей синтез-газ будет применен в промышленности, и т.д. Чаще всего синтез-газ второстепенный продукт, который получается в процессе производства полукокса и может быть просто сожжен в свече. 


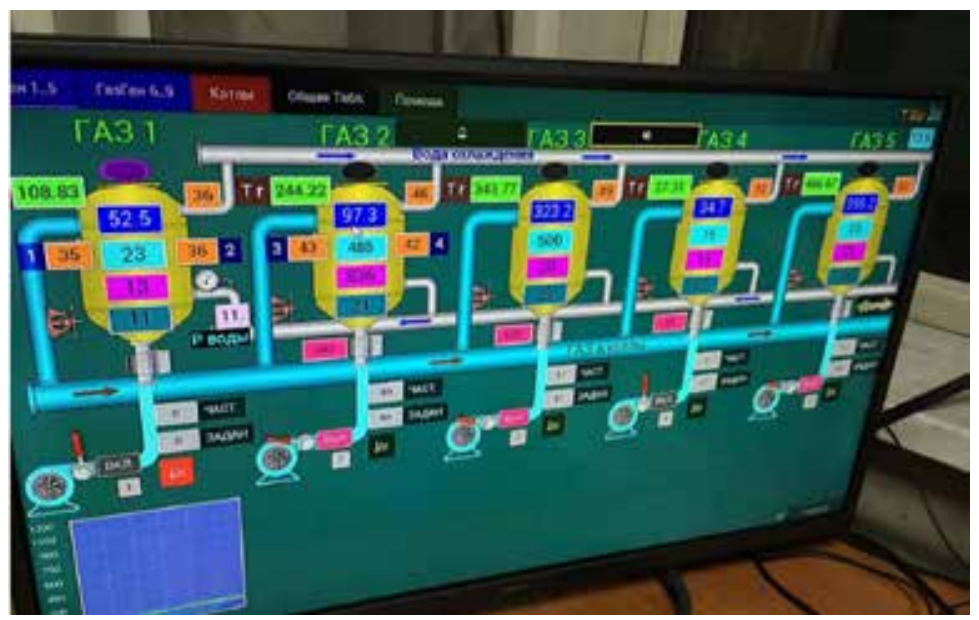

Рис. 5. Система управления процессом газификации угля

Fig. 5. Coal gasification control system

В литературе много примеров описания доменного газа или коксового газа, созданы целые промышленные хозяйства по применению вторичных энергетических ресурсов при промышленном производстве кокса для металлургии. В таких случаях объемы газа огромны и не использовать его просто нецелесообразно, коксовый газ является высококалорийным, теплота его сгорания достигает 18 МДж/м³. Такой газ возможно транспортировать на дальние расстояния, и чаще всего его используют для производства полиэтилена и в качестве химического сырья. Доменный газ менее калорийный по сравнению с коксовым, его не используют в доменных печах как основное топливо в связи с тем, что он не может поднять необходимые температуры для технологических процессов внутри печи, поэтому доменный газ используют только на подогрев воздушного дутья для доменных печей. В табл. 5 и 6 приведена теплота сгорания синтез-газа, полученного при газификации угля и биотоплива из древесины [39-45].

Таблица 5. Теплота сгорания различных синтез-газов из угля

Table 5. Heat of combustion of various synthesis gases from coal

\begin{tabular}{|l|c|}
\hline \multicolumn{1}{|c|}{ Вид и способ получения синтез-газа } & $\begin{array}{c}\text { Теплота сгорания, } \\
\text { МДж/м }\end{array}$ \\
\hline \multicolumn{1}{|c|}{1} & 2 \\
\hline Природный газ & $34-38$ \\
\hline Доменный газ & 3,93 \\
\hline Коксование каменных углей при $1000-1100{ }^{\circ} \mathrm{C}$ & $8,38-12,57$ \\
\hline Полукоксование бурых углей при $500-550{ }^{\circ} \mathrm{C}$ & 15,13 \\
\hline Генераторный газ при газификации под высоким давлением & 6,03 \\
\hline Генераторный газ из: & 5,15 \\
\hline каменного угля & \\
\hline донецкого антрацита & \\
\hline
\end{tabular}


Продолжение табл. 5

Continued Table 5

\begin{tabular}{|c|c|}
\hline 1 & 2 \\
\hline коксовой мелочи & 5,29 \\
\hline богословского угля (месторождение закрыто в 2000 году) & 5,45 \\
\hline сулюктинского угля & 5,62 \\
\hline подмосковного угля (месторождение закрыто в 2009 году) & 5,9 \\
\hline челябинского угля & 6,07 \\
\hline лисичанского угля - разновидности угля Донецкого угольного разреза & 6,08 \\
\hline черемховского угля - Иркутский угольный бассейн & 6,08 \\
\hline гидроторфа & 6,24 \\
\hline Багенум, Nuon Power (Нидерланды) из каменного угля & 11,5 \\
\hline Вабаш Ривер, Destec, PSI из каменного угля / нефтекокс & 11,5 \\
\hline Полк Tampa el., США из каменного угля & 9,3 \\
\hline Портолано, Elcogas, Испания из угля / нефтекокс & 10,0 \\
\hline $\begin{array}{l}\text { Газификация в кипящем слое высокозольного угля месторождения Раджмахал, } \\
\text { Индия }\end{array}$ & $3,06-5,2$ \\
\hline $\begin{array}{l}\text { Газификация в кипящем слое высокозольного угля месторождения Северного } \\
\text { Каранпура, Индия }\end{array}$ & $2,2-3,79$ \\
\hline Паровая газификация бурых улей месторождения Шиве-Овоо, Монголия & 8,67 \\
\hline Паровая газификация бурых улей месторождения Ховил, Монголия & 9,03 \\
\hline Паровая газификация бурых улей месторождения Багануур, Монголия & 8,95 \\
\hline $\begin{array}{l}\text { Паровая газификация бурых улей Бородинского месторождения, входящего в } \\
\text { КАбасс, Россия }\end{array}$ & 9,12 \\
\hline $\begin{array}{l}\text { Газификация угля Березовского разреза с применением взвешенного слоя с } \\
\text { центральным высокоскоростным потоком дутья }\end{array}$ & 4,7 \\
\hline
\end{tabular}

Таблица 6. Теплота сгорания синтез-газа из биотоплива (древесина)

Table 6. Heat of combustion of synthesis gas from biofuels (wood)

\begin{tabular}{|c|c|}
\hline Вид и способ получения синтез-газа & $\begin{array}{c}\text { Теплота сгорания, } \\
\text { МДж/м }{ }^{3}\end{array}$ \\
\hline Газификация еловых палений, $\mathrm{W}=38$ \% & 5,6 \\
\hline Газификация еловой щепы, $\mathrm{W}=38$ \% & 7,0 \\
\hline Газификация еловой щепы в промышленном газогенераторе, $\mathrm{W}=46,8$ \% & 6,19 \\
\hline Газификация березовой щепы в промышленном газогенераторе, $\mathrm{W}=44,6$ \% & 6,3 \\
\hline Из лесопильных сухих еловых отходов & 5,02 \\
\hline Из лесопильных сухих березовых отходов & 5,85 \\
\hline
\end{tabular}

\section{Промышленное применение технологий газификации топлива за рубежом}

Со временем ископаемое топливо будет заменено биотопливом либо их смесью, полученной из различных видов биомасс и углей для их совместной газификации, т. к. газифици- 
ровать ископаемое топливо для получения только электрической и тепловой энергии экономически невыгодно оттого, что основное ценное сырье при газификации угля - это полукокс и только в локальных случаях основным топливом может быть жидкое или газообразное топливо [46-48].

Лидером в применении термохимической переработки угля является Китай [49-50]. Самые крупные газифицирующие предприятия достигают выработки до 9300 МВт в производстве жидкого топлива путем газификации угля. На рис. 6 изображены одни из самых крупных предприятий в мире с использованием газификации углей для получения жидкого топлива, синтез-газа, 35 \% мирового производства метанола и электрической энергии. На некоторых предприятиях количество газогенераторов достигает 48 штук.

Среди технологий преобразования топлива в электроэнергию мы рассмотрим процесс, изображенный на рис. 7 - «Комбинированный цикл комплексной газификации биомассы (BIGCC)», т. к. он является потенциально эффективным методом из-за высокой степени преобразования топлива для выработки электрической энергии. Среди технологий преобразования биомассы в электроэнергию BIGCC исследуется с 1990-х годов. Система BIGCC является прототипом электростанций с интегрированным циклом газификации углей (IGCC), в России аналог этих систем называется внутрицикловой газификацией (ВЦГ). Было разработано несколько заводов на основе BIGCC: завод Thermie Energy Farm (Италия), завод Arbre (Англия), Biocycle (Дания) и завод Varnamo (Швеция) [51-52].

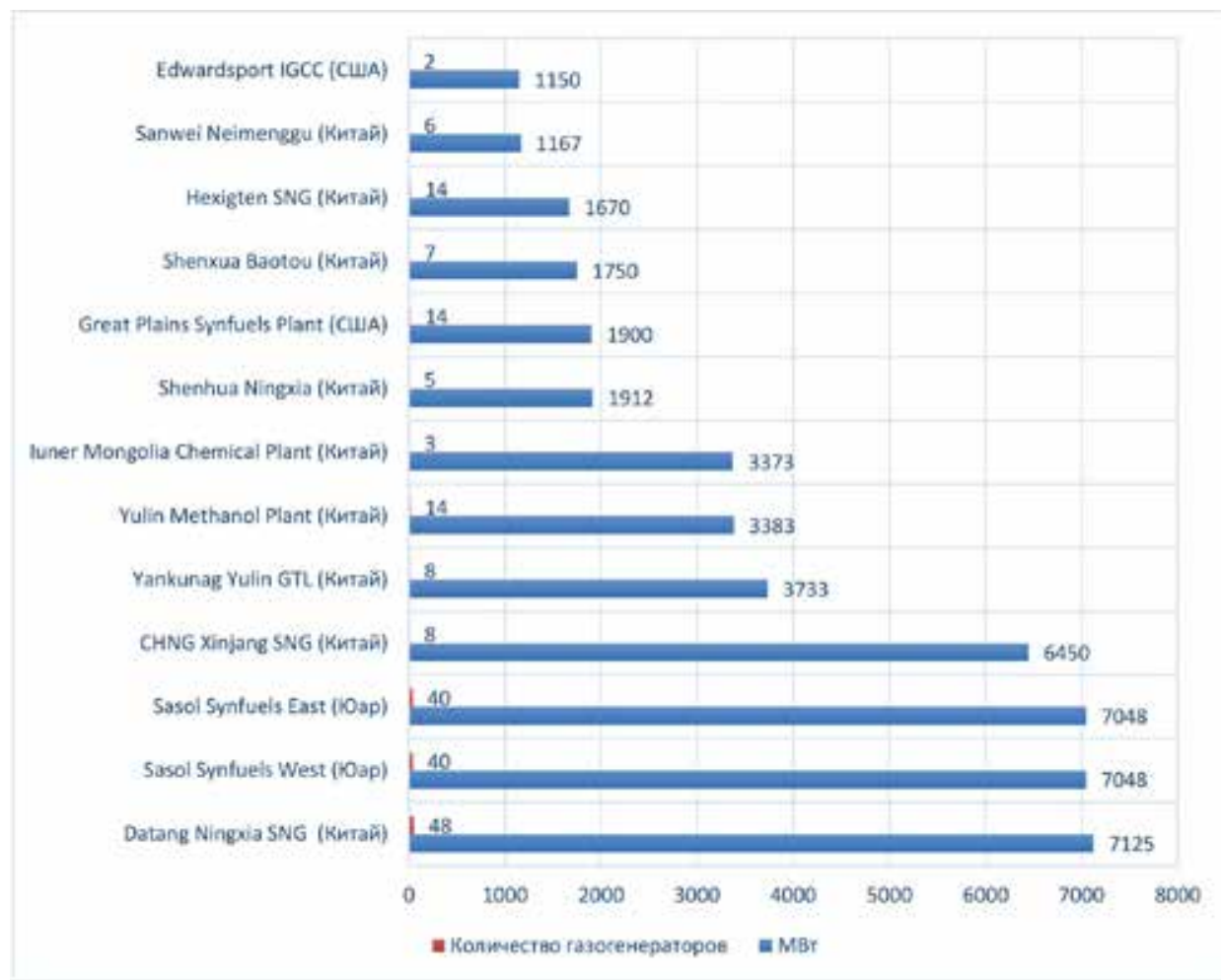

Рис. 6. Крупные зарубежные промышленные предприятия, использующие газификацию угля

Fig. 6. Large foreign industrial enterprises using coal gasification 


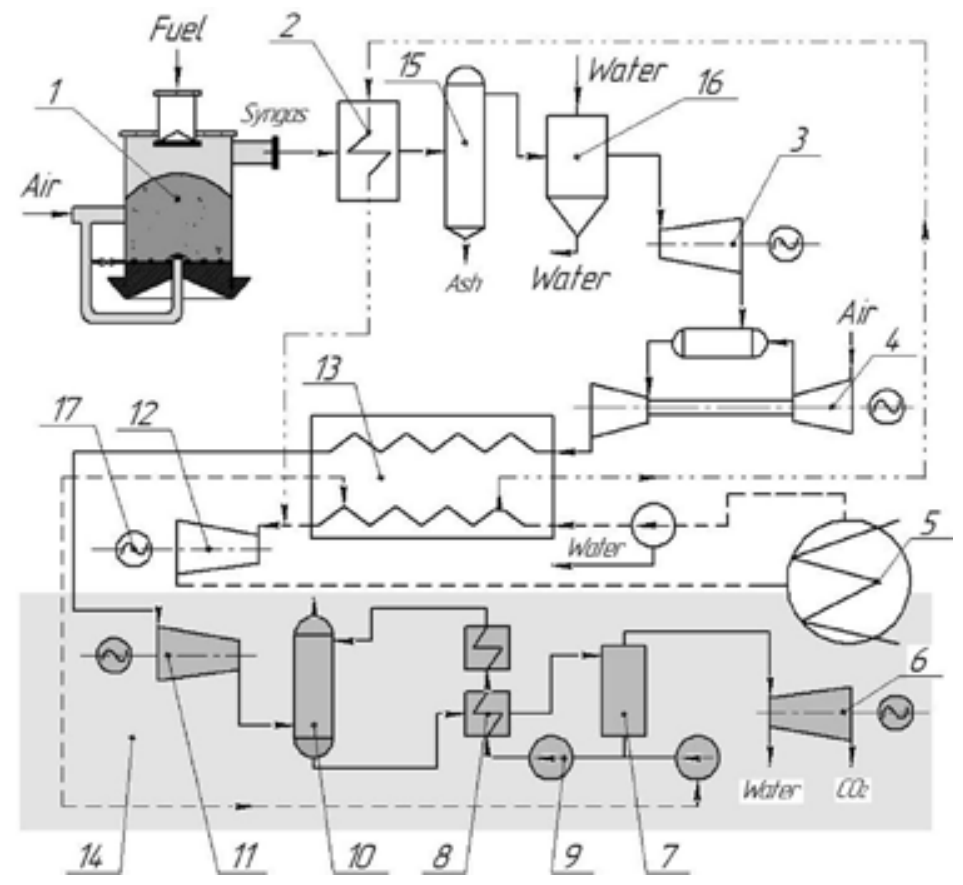

Рис. 7. Комбинированный цикл комплексной газификации биомассы (1 - газогенератор; 2 - котелутилизатор; 3 - турбокомпрессор высокого давления; 4 - газовая турбина; 5 - конденсатор; 6 - компрессор; 7 - выпарная колонна; 8 - теплообменник; 9 - насос; 10 - абсорбер; 11 - дутьевой вентилятор; 12 паровая турбина; 13 - парогенератор с рекуперацией тепла; 14 - технология улавливания и переработки углекислого газа; 15 - циклонный сепаратор; 16 - скруббер; 17 - генератор электрической энергии)

Fig. 7. Combined cycle of complex gasification of biomass (1 - gasifier; 2 - boiler utilizer; 3 - high pressure turbocompressor; 4 - gas turbine; 5 - condenser; 6 - compressor; 7 - evaporation column; 8 - heat exchanger; 9 - pump; 10 - absorber; 11 - blowing fan; 12 - steam turbine; 13 - steam generator with heat recovery; 14 technology of carbon dioxide capture and processing; 15 - cyclone separator; 16 - scrubber; 17 - electric power generator)

Система выработки электроэнергии BIGCC состоит в основном из пяти основных узлов: газификация биомассы (опилки сосны), очистка газа, газовая турбина, парогенератор с рекуперацией тепла и паровая турбина. Первым этапом является газификация биомассы в генераторе газа, где частицы биомассы термически газифицируются в генераторный газ, содержащий

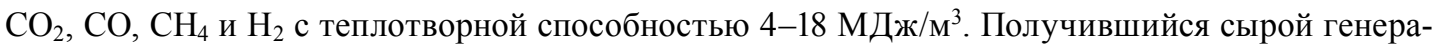
торный газ поступает в котел-утилизатор где охлаждается до $200{ }^{\circ} \mathrm{C}$, проходит предварительную очистку для использования в турбине. Вначале удаляется летучая зола в циклоне, далее газ попадает в скруббер, где при помощи воды происходит его дополнительная очистка для входа в турбокомпрессор высокого давления.

Пройдя компрессор, чистый генераторный газ вводится в камеру сгорания газовой турбины для выработки электрической энергии. Тепло из газовой турбины направляется в парогенератор с рекуперацией тепла для подогрева пара. Далее пар с температурой $505{ }^{\circ} \mathrm{C}$ и давлением 103 бара входит в паровую турбину для выработки электрической энергии, а отработанный пар конденсируется для повторного использования в системе BIGCC. Этот циклический процесс построен на основе цикла Ренкина [53]. 


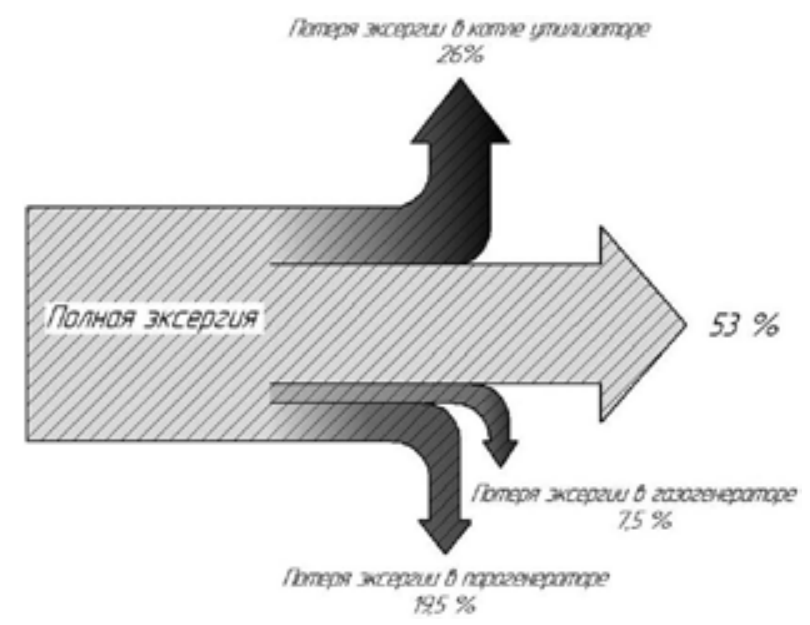

Рис. 8. Эксергетический анализ BIGCC

Fig. 8. Exergetic analysis BIGCC

Результаты эксергетического анализа системы BIGCC представлены на рис. 8 [54]. Самые высокие потери произошли в котле-утилизаторе из-за необратимого процесса горения топлива, в парогенераторе с рекуперацией тепла и в газогенераторе. Максимальная работа из заданного количества тепла при обратимой интеграции из начального состояния в стадию равновесия с окружающей средой определялась по формуле:

$$
E=Q\left(1-\frac{T_{0}}{T}\right)
$$

где $E$ - максимальная работа системы (эксергия), $Q$ - количество теплоты системы, $T$ - абсолютная температура теплоносителя, $T_{0}$ - абсолютная температура окружающей среды.

Удельная эксергия потоков для твердых, газообразных и жидких тел, исходя из первого и второго законов термодинамики, определялась как

$$
e=i-i_{0}-T_{0}\left(S-S_{0}\right)
$$

где $i_{0}$ и $S_{0}$ - энтальпия и энтропия рабочего тела. Эксергия увеличивается при нагреве исходных компонентов горения для снижения разницы температур. В сложных случаях, примером которого выступает система BIGCC, эксергетический анализ является дополнительной характеристикой к тепловым балансам.

Технология улавливания и переработки углекислого газа (CCS), представленная на рис. 2 , является методом для удаления углекислого газа при выработке электроэнергии. Существует три технологии CCS: улавливание углерода после сгорания, сжигание кислородного топлива и улавливание углерода до сгорания [55-56].

\section{Получение синтез-газа в процессе пиролиза}

Еще один метод термохимической обработки топлива - это пиролиз, заключающийся в термической деполимеризация органического вещества в отсутствие кислорода. Состав и выход продуктов пиролиза из условного топлива зависит от следующих факторов (способа

$$
-396-
$$


пиролиза, влажности условного топлива, теплотворных свойств топлива, содержания выхода летучих, золы и т.д.) и рабочих факторов (состава газа, скорости нагрева, температуры процесса и др.). Быстрый нагрев биомассы в такой инертной атмосфере приводит к образованию органических паров, состоящих из фрагментов полимеров целлюлозы, гемицеллюлозы и лигнина, обнаруженных в биомассе [57-67].

Процесс пиролиза характеризуется термохическим разложением исходного сырья без присутствия кислорода или с минимальным количеством кислорода, чем требуется для газификации или полного сгорания. Существует значительная разница между пиролизом и газификацией. Газификация характеризуется разложением биомассы в синтез-газ путем тщательного контроля количества присутствующего кислорода. Применительно к биомассе термин «пиролиз» довольно сложно определить. В обзоре недавней литературы под пиролизом понимается описание процесса, в котором биомасла являются основными продуктами. Время, необходимое для пиролиза, значительно меньше чем для газификации. Ниже мы рассмотрим разные виды пиролиза биомассы.

В Томском политехническом университете под руководством доктора технических наук А.С. Заворина исследуют термическую деструкцию топлива в условиях низкотемпературного пиролиза, в табл. 7 представлена часть результатов, полученных при низкотемпературном пиролизе биомассы и торфа [68-73].

Tectona grandis. Ученые Бенаресского индусского университета совместно с учеными из CSIR-Центрального института исследований горного дела и топлива в своей работе исследовали опилки тикового дерева индийского происхождения, которые были подвержены пиролизной обработке перед предварительной сушкой и измельчением до нужного размера. Получившийся биогаз (помимо биомасла и биоугля) состоял в основном из водорода $\left(\mathrm{H}_{2}\right)$, метана $\left(\mathrm{CH}_{4}\right)$, оксида углерода $(\mathrm{CO})$ и диоксида углерода $\left(\mathrm{CO}_{2}\right)$. Наличие метана и водорода в составе газа говорит о хороших его топливных свойствах, и он может быть использован для выработки энергии. Высшая теплота сгорания составила 7,01 МДж/м³ [74-76].

Oil palm biomass. Биомассу масляной пальмы изучили ученые из Университета принца Сонгкла. Получившийся пиролизный газ имеет малое содержание водорода, метана, оксида

Таблица 7. Теплота сгорания синтез-газа, полученного путем низкотемпературного пиролиза Table 7. Combustion heat of synthesis gas obtained by low-temperature pyrolysis

\begin{tabular}{|l|c|}
\hline \multicolumn{1}{|c|}{ Биомасса } & $\begin{array}{c}\text { Теплота сгорания } \\
\text { синтез-газа, МДж/м }\end{array}$ \\
\hline Солома & 12,1 \\
\hline Отруби пшеницы & 10,9 \\
\hline Скорлупа кедрового ореха & 13,5 \\
\hline Щепа из различных пород дерева (береза, сосна и осина) & 9,0 \\
\hline Опилки из сосны & 10,7 \\
\hline Торф из Томского месторождения & 7,6 \\
\hline Торф из Суховского месторождения & 9,3 \\
\hline Торф из Аркадиевского месторождения & 6,8 \\
\hline
\end{tabular}


углерода и диоксида углерода, что делает его малопригодным для получения энергии. Высшая

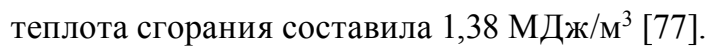

Punica granatum L. Кожуру граната использовали как биомассу для пиролиза ученые Габесского университета Туниса и Национального института угольной промышленности Испании. Получившийся биогаз при мгновенном пиролизе с температурой $850{ }^{\circ} \mathrm{C}$ содержал: $\mathrm{CO}_{2}$, $\mathrm{CO}, \mathrm{H} 2, \mathrm{CH}_{4}$ и, в меньшей степени, кислород и другие углеводороды, такие как $\mathrm{C}_{2} \mathrm{H}_{4}, \mathrm{C}_{2} \mathrm{H}_{6}$, $\mathrm{C}_{3} \mathrm{H}_{6}, \mathrm{C}_{4} \mathrm{H}_{6}$, и имел наивысшую теплоту сгорания $Q_{\text {в }}=11,5$ МДж/кг [78].

Olea europaea, Quercus ilex, Vitis vinifera, Коллектив ученых из Германии, Италии и Великобритании исследовал три вида биомассы: $a$ ) обрезки оливковых деревьев; $b$ ) обрезки каменного дуба; $c$ ) обрезки виноградной лозы. Получившийся биогаз в основном состоял из водорода (в большей степени), оксида углерода, метана и диоксида углерода. Причем состав газов всех трех биомасс был похож. Наивысшая теплота сгорания этих газов варьировалась в пределах 14,6-14,9 МДж/кг при плотности газа 0,9 кг/м³ [79-81].

Ученые из Института проблем использования природных ресурсов и экологии Национальной академии наук Беларуси исследовали свойства опилок ивы, ольхи, опилок ольхи с добавлением катализатора, смесь сосновых и пихтовых опилок методами медленного и быстрого пиролиза с использованием лабораторных установок - пиролизных реакторов для пиролиза с неподвижным топливным слоем и горизонтальным пиролизом. Образование водорода, высокое содержание которого (28-39 \%) характерно для всех исследуемых веществ, в процессе быстрого пиролиза происходит в основном за счет вторичных реакций - взаимодействия парогазовой смеси с коксом. Пиролиз опилок ольхи проводили с использованием катализатора, через который пропускали парогазовую смесь, и подвергали ее таким образом дополнительной термохимической обработке при той же температуре, что увеличивало выход пиролизного газа (до 85 \%) без заметных изменений в его составе [82].

Walnut shell. Коллектив ученых из Индийского технологического института установил, что пиролизный газ начинает выходить при температуре $300{ }^{\circ} \mathrm{C}$ и с ее увеличением до $600{ }^{\circ} \mathrm{C}$

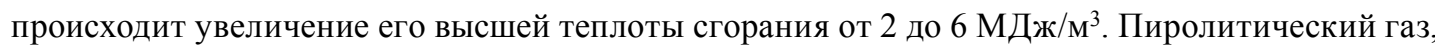
полученный медленным пиролизом, имеет удовлетворительный уровень горючего вещества, что делает его пригодным для использования в качестве газообразного топлива после определенных модификаций [83].

Jatropha curcas L. B Техасском университете A\&M исследовали семена дерева ятрофы. Под прессом из семян было удалено масло, а сам жмых был помещен в настольный реактор для пиролиза с автоматическим регулятором температуры. Общая теплотворная способность полученного газа увеличивалась с 0,1 МДж/кг при $400{ }^{\circ} \mathrm{C}$ до 4,2 МДж/кг при $600{ }^{\circ} \mathrm{C}$ [84-86].

\section{Заключение}

Исследования процессов термохимической переработки топлива в синтез-газ являются перспективным направлением в энергетике XXI века. Перевод существующих малых промышленных котельных на сжигание синтез-газа даст экономический и экологический эффект для Красноярского края. 
Тем не менее при переводе промышленных предприятий на использование синтез-газа (замещая уголь) или на дорогостоящее мазутное топливо остается ряд задач, над которыми авторы ведут работу - это:

- низкая калорийность синтез-газа по сравнению с углем, мазутом и природным газом;

- нестабильная работа котлов, переведенных на сжигание синтез-газа;

- влияние совместного сжигания синтез-газа и угля на снижение вредных выбросов;

- применение синтез-газа для растопки паровых и водогрейных котлов.

\section{Список литературы / References}

[1] Ziegler C., Morelli V., Fawibe O. Climate change and underserved communities, Physician Assistant Clinics, 2019, 4 (1), 203-216. Access: https://doi.org/10.1016/j.cpha.2018.08.008

[2] Некрасов Н. Заменители нефтепродуктов. М.: Госпланиздат, 1943. 60 с. [Necrasov N. Substitutes of oil processing. Moscow: Gosplanizdat, 1943. 60 p. (In Russian)].

[3] Медников А.С. Обзор технологий многоступенчатой газификации древесной биомассы, Теплоэнергетика, 2018, 8, 47-64 [Mednikov A.S. Review of technologies of multi-stage gasification of wood biomass. Thermal power engineering, 2018, 8, 47-64 (In Russian)].

[4] Малолетнев А.С., Гюльмалиев А.М., Рябов Д.Ю. и др. Термодинамический анализ газификации угля Даурского месторождения. Химия твердого топлива, 2013, 1, 35-39 [Myunev A.S., Gulmaliyev A.M., Ryabov D.Y., etc. Thermodynamic Analysis of Coal Gasification of Daurskoye Deposit. Solid Fuel Chemistry, 2013, 1, 35-39 (In Russian)].

[5] Калечица И.В. Химические вещества из угля. М.: Химия, 1980. 616 с. [Kalechica I.V. Chemicals from coal. M.: Chemistry, 1980. 616 p. (In Russian)].

[6] Wang Y., Liu Q. Production of syngas from steam gasification of three different ranks of coals and related reaction kinetics, Journal of the Energy Institute, 93 (2020), 533-541. Access: https://doi. org/10.1016/j.joei.2019.06.011

[7] Лямин В.Я. Газификация древесины. М.: Лесная промышленность, 1967. 262 с. [Lyamin V.J. Wood gasification. Moscow: Forestry industry, 1967. 262 p. (In Russian)].

[8] Кислов В.М., Глазов С.В., Червонная Н.А. и др. Газификация биомассы в режиме горения со сверхадиабатическим разогревом. Химия твердого топлива, 2008, 3, 9-14 [Kislov V.M., Glazov S.V., Wormonaya N.A. et. al. Combustion gasification of biomass with superadiabatic heating. Solid fuel chemistry, 2008, 3, 9-14 (In Russian)].

[9] Wu R., Beutler J. Biomass char particle surface area and porosity dynamics during gasification. Fuel. 264 (2020) 116833. Access: https://doi.org/10.1016/j.fuel.2019.116833

[10] Кузнецов П.Н. Свойства бурых углей как сырья для технологической переработки. Химия твердого топлива, 2013, 6, 19-23 [Kuznetsov P.N. Properties of brown coals as raw materials for technological processing. Solid fuel chemistry, 2013, 6, 19-23 (In Russian)].

[11] Guan G. Clean coal technologies in Japan: A review. Chinese Journal of Chemical Engineering, 2017, 25 (6), 689-697. DOI: 10.1016/j.cjche.2016.12.008.

[12] Конторович Б.В. Введение в теорию горения и газификация твердого топлива. М.: Металлургиздат, 1960. 360 с. [Kontorovich B.V. Introduction to combustion theory and solid fuel gasification. Moscow: Metallurgical, 1960. 360 p. (In Russian)]. 
[13] Кузнецов П.Н., Каменский Е.С., Кузнецова Л.И. и др. Влияние соединений кальция на процесс паровой газификации карбонизированных бурых углей. Химия твердого топлива, 2019, 1, 41-47 [Kuznetsov P.N., Kamensky E.S., Kuznetsov L.I. et al. Effects of Calcium Compounds on the Steam Gasification of Carbonized Brown Coals. Solid Fuel Chemistry, 2019, 1, 41-47 (In Russian)].

[14] Кулиш В.А., Брицкий Р.Е. О заменен угля на газ, полученный из угля на тепловых электростанциях. Уголь Украины, 2016, 1, 38-42 [Kulish V.A., Bricki R.E. On replaced coal with gas produced from coal at thermal power plants. Coal of Ukraine, 2016, 1, 38-42 (In Ukraine)].

[15] Salam M.A., Ahmed K. et al. A review of hydrogen production via biomass gasification and its prospect in Bangladesh. International Journal of Hydrogen Energy, 2018, 43 (32), 1494414973. DOI: 10.1016/j.ijhydene.2018.06.043.

[16] Щипко М.Л., Павлов В.П., Волова Т.Г., Кузнецов Б.Н. и др. Фундаментальные основы комплексной переработки углей КАТЭКа для получения энергии, синтез-газа и новых материалов с заданными свойствами: Монография - Новосибирск: СО РАН, 2005. 219 с. ISBN 5-7692-0759-0 [Schipko M.L., Pavlov V.P., Volova T.G., Kuznetsov B.N. et al. Fundamental foundations of complex processing of KATEK coal for production of energy, synthesis gas and new materials with specified properties: Monograph - Novosibirsk: CO RAS, 2005. 219 p. (in Russian)].

[17] Стрижакова Ю.А., Мовсум-заде Н.Ч., Авакян Т.А. и др. Оценка процесса газификации Ленинградских горючих сланцев. Химия твердого топлива, 2012, 4, 35-38 [Strigakov Yu.A., Movsum-zade N.H., Avakyan T.A. et al. Assessment of the process of gasification of Leningrad oil shale. Solid fuel chemistry, 2012, 4, 35-38 (In Russian)].

[18] Афанасьев В.В., Ковалев В.Г., Тарасов В.А., Алексеев С.Н. Исследование возможностей использования синтез-газа для стабилизации горения факела пылеугольных котлов. Вестник Чувашского университета, 2012, 3, 100-104 [Athaniev V.V., Kovalev V.G., Tarasov V.A., Alekseyev S.N. Study of possibilities of using synthesis gas for stabilization of combustion of pulverized coal boilers. Journal of Chuvash University, 2012, 3, 100-104 (In Russian)].

[19] Mallick D., Mahanta P., Moholkar V.S. Co-gasification of coal and biomass blends: Chemistry and engineering. Fuel, 2017, 204, 106-128. DOI: 10.1016/j.fuel.2017.05.006.

[20] You S., Ok Y.S. et al. Towards practical application of gasification: a critical review from syngas and biochar perspectives. Critical Reviews in Environmental Science and Technology, 2018, 48 (22-24), 1165-1213. 1165-1213. DOI: 10.1080/10643389.2018.1518860.

[21] Донской И.Г., Кейко А.В., Козлов А.В. Расчет режимов слоевой газификации угля с помощью термодинамической модели с макрокинетическими ограничениями. Теплоэнергетика, 2013, 12, 56-61 [Donskoy I.G., Keiko A.V., Kozlov A.V. Calculation of coal layer gasification modes using thermodynamic model with macrokinetic limitations. Thermal power engineering, 2013, 12, 56-61 (In Russian)].

[22] Баласанов А.В., Усачев А.Б., Комков А.А., Федоров А.Н., Дитятовский Л.И. Перспективы использования высокотемпературной газификации твердого топлива в шлаковом расплаве. Уголь, 2013, 10, 61-64 [Balasanov A.V., Usachev A.B., Komkov A.A., Fyodorov A.N., Dityatovsky L.I. Prospects of using high-temperature gasification of solid fuel in slag melt. Coal, 2013, 10, 61-64 (In Russian)]. 
[23] Alharthi M.A., Khaliq A., Luqman M. Thermodynamic analysis of a gasifier-based coal-tofuel cogeneration system. International Journal of Exergy, 2020, 31 (2), 186-215. Access: https://doi. org/10.1504/IJEX.2020.105489 .

[24] Кузнецов П.Н., Колесникова С.М., Белаш М.Ю. Влияние минеральных компонентов на реакционную способность буроугольных карбонизатов при паровой газификации. Химия твердого топлива, 2011, 2, 60-64 [Kuznetsov P.N., Kolesnikov S.M., Belash M.Y. Influence of mineral components on reactivity of brown-coal carbonates during steam gasification. Chemistry of solid fuel, 2011, 2, 60-64 (In Russian)].

[25] Лебедев А.С., Симин Н.О., Юшкевич А.В. Работа камер сгорания ГТУ на продуктах газификации твердого топлива. Теплоэнергетика, 2010, 9, 73-79 [Lebedev A.S., Simin N.O., Yushkevich A.V. Operation of GTU combustion chambers on solid fuel gasification products. Thermal power engineering, 2010, 9, 73-79 (In Russian)].

[26] Dwivedi K.K., Karmakar M.K. et al. A brief review on hydrodynamic behaviour analysis of coal gasification in a circulating fluidized bed gasifier. International Journal of Heat and Technology, 2019, 37 (3), 792-802. DOI: 10.18280/ijht.370316.

[27] Ноздренко Г.В., Щинников П.А., Боруш О.В., Григорьева О.К., Кузьмин А.Г. Комбинированное производство электро- и теплоэнергии, синтез-газа и водорода из угля. Энергобезопасность и энергосбережение, 2011, 1(37), 18-23 [Nosdrenko G.V., Schinnikov P.A., Borush O.V., Grigoriev O.K., Kuzmin A.G. Combined production of electric and thermal energy, synthesis gas and hydrogen from coal. Energy safety and energy saving, 2011, 1(37), 18-23 (In Russian)].

[28] Мухина Т.Н., Барабанов Н.Л., Бабаш С.Е. и др. Пиролиз углеводородного сырья. М.: Химия, 1987. 240 c. [Mukhina T.N., Barabanov N.L., Babash S.E. et al. Pyrolysis of hydrocarbon raw material. M.: Chemistry, 1987. 240 p. (In Russian)].

[29] Dhyania V., Bhaskar T.A comprehensive review on the pyrolysis of lignocellulosic biomass. Renewable Energy, 2018, 129, 695-716. Access: https://doi.org/10.1016/j.renene.2017.04.035.

[30] Inayat M., Sulaiman S.A. et al. Effect of various blended fuels on syngas quality and performance in catalytic co-gasification: A review. Renewable and Sustainable Energy Reviews, 2019, 105, 252-267. DOI: 10.1016/j.rser.2019.01.059.

[31] Xiang Y., Cai L., Guan Y., Liu W. et al. Study on the biomass-based integrated gasification combined cycle with negative $\mathrm{CO}_{2}$ emissions under different temperatures and pressures. Energy, 2019, 179, 571-580. Access: https://doi.org/10.1016/j.energy.2019.05.011 .

[32] Исламов С.Р., Степанов С.Г. Глубокая переработка угля: введение в проблему выбора технологии. Уголь, 2007, 10(978), 55-58. [Islamov S.R., Stepanov S.G. Deep coal processing: introduction to the problem of technology choice. Coal, 2007, 10(978), 55-58. (In Russian)]

[33] Степанов С.Г. Разработка автотермических технологий переработки угля. Автореф. дис. ... докт. техн. наук. Красноярск, 2003. 40 с. [Stepanov S.G. Development of autothermal coal processing technologies. Thesis ... doct. of tech. Sci. Krasnoyarsk, 2003. 40 p. (In Russian)]

[34] Исламов С.Р. Энергоэффективное использование бурых углей на основе концепиии «Термококс». Автореф. дис. ... докт. техн. наук. Красноярск, 2010. 40 с. [Islamov S.R. Energy efficient use of brown coal based on the concept of "Thermocox". Thesis ... doct. of tech. Sci. Krasnoyarsk, 2010. 40 p. (In Russian)] 
[35] Морозов А.Б. Разработка автотермической технологии производства полукокса и активированного угля. Автореф. дис. ... канд. техн. наук. Красноярск, 2003, 20 с. [Morozov A.В. Development of autothermal technology of semi-coke and activated carbon production. Thesis ... cand. of tech. Sci. Krasnoyarsk, 2003. 20 p. (In Russian)]

[36] Михалев И.О., Исламов С.Р. Энерготехнологическая переработка бурого угля Балахтинского месторождения: инновационный подход к энергоэффективности в регионе, Becmник СибГАУ, 2010, 5, 145-147. [Mikhalev I.O., Islamov C.R. Energy Processing of Brown Coal of Balakhtinskoye Field: Innovative Approach to Energy Efficiency in the Region, SibGAU Gazette, 2010, 5, 145-147. (In Russian)]

[37] Логинов Д.А., Исламов С.Р., Степанов С.Г., Кочетков В.Н. Получение сорбента из низкозольного бурого угля. Химия твердого топлива, 2016, 2, 46-50. [Loginov D.A., Islamov S.R., Stepanov S.G., Kochetkov V.N. Obtaining sorbent from low-ash brown coal. Solid fuel chemistry, 2016, 2, 46-50. (In Russian)]

[38] Латышев В.П., Мельник С.В., Казанцева Н.И., Шевченко Г.Г. Технология производства горючего газа из бурых углей в газогенераторе кипящего слоя. Химия и химическая технология, 2008, 51 (12), 77-79 [Latyshev V.P., Melnik S.V., Kazantseva N.I., Shevchenko G.G. Technology of Production of Combustible Gas from Brown Coal in Gas Generator of the Boiling Bed. Chemistry and Chemical Technology, 2008, 51 (12), 77-79 (In Russian)].

[39] Чаван П., Датта С., Саха С., Саха Г., Шарма Т. Газификация в кипящем слое высокозольных углей Индии. Химия твердого топлива, 2012, 2, 40-46 [Chavan P., Datta S., Sakha S., Sakha G., Sharma T. Gasification in the boiling layer of high-ash coals of India. Chemistry of solid fuel, 2012, 2, 40-46 (In Russian)].

[40] Юренева В.Н., Лебедева П.Д. Теплотехнический справочник. М.: Энергия, 1975. 744 c. [Yureneva V.N., Lebedeva P.D. Thermotechnical Directory, M.: Energia, 1975. 744 p. (In Russian)].

[41] Беляев А.А. Газификация низкосортных топлив в фонтанирующем слое для производства электроэнергии. Химия твердого топлива, 2008, 6, 14-21 [Bialiaev A.A. Gasification of low-grade fuels in the fountain layer for power generation. Solid fuel chemistry, 2008, 6, 14-21 (In Russian)].

[42] Рыжков А.Ф., Богатова Т.Ф, Вальцев Н.В. и др. Разработка низкотемпературных реакторов термохимической конверсии для угольной энергетики. Теплоэнергетика, 2013, 12, 47-55 [Ryzhkov A.F., Bogatova T.F., Valtsev N.V., etc. Development of low-temperature thermochemical conversion reactors for coal power. Thermal power engineering, 2013, 12, 47-55 (In Russian)].

[43] Стариков А.П., Харитонов В.Г., Гордиенко А.И. Перспективы глубокой переработки углей России газификацией с получением продуктов высокой добавленной стоимости. Уголь, 2012, 3, 52-54 [Starkov A.P., Kharitonov V.G., Gordienko A.I. Prospects of deep processing of coal of Russia by gasification with production of products of high added value. Coal, 2012, 3, 52-54 (In Russian)].

[44] Кузнецов П.Н., Колесникова С.М., Кузнецова Л.И., и др. Паровая газификация углей Монголии. Химия твердого топлива, 2015, 2, 24-30 [Kuznetsov P.N., Kolesnikov S.M., Kuznetsov L.I. et al. Steam gasification of coal of Mongolia. Solid fuel chemistry, 2015, 2, 24-30(In Russian)]. 
[45] Донской И.Г., Козлов А.Н. Свищев Д.А. и др. Расчетное исследование эффективности ступенчатого процесса газификации влажной древесины. Теплоэнергетика, 2017, 4, 21-29 [Donskoy I.G., Kozlov A.N. Svischev D.A., et al. Design study of efficiency of step-by-step process of wet wood gasification. Thermal power engineering, 2017, 4, 21-29 (In Russian)].

[46] Cabuk B., Duman, G. et al. Effect of fuel blend composition on hydrogen yield in cogasification of coal and non-woody biomass. International Journal of hydrogen energy, 2020, 45, 3435-3443. https://doi.org/10.1016/j.ijhydene.2019.02.130 .

[47] Kok M.V., Betul Yildirim B. Gasification kinetics of Thrace region coal by thermogravimetry analysis. Journal of Petroleum Science and Engineering, 188 (2020), 106869. Access: https://doi. org/10.1016/j.petrol.2019.106869 .

[48] Warda C., Goldsteinb H. et al. Making coal relevant for small scale applications: Modular gasification for syngas/engine CHP applications in challenging environments. Fuel, 267 (2020), 117303. Access: https://doi.org/10.1016/j.fuel.2020.117303 .

[49] Jeonga Y.S., Parkb K.B., Kim J.S. Hydrogen production from steam gasification of polyethylene using a twostage gasifier and active carbon. Applied Energy, 262 (2020), 114495. Access: https://doi.org/10.1016/j.apenergy.2020.114495.

[50] Ольховский Г.Г. Газификация твердых топлив в мировой энергетике (Обзор), Теплоэнергетика, 2015, 7, 3-11 [Olkhovsky G.G. Gasification of solid fuels in world energy (Overview). Thermal power engineering, 2015, 7, 3-11 (In Russian)].

[51] Ge H., Zhang H., Guo W., Song T., Shen L. System simulation and experimental verification: Biomass-based integrated gasification combined cycle (BIGCC) coupling with chemical looping gasification (CLG) for power generation. Fuel, 2019, 241, 118-128. Access: https://doi.org/10.1016/j. fuel.2018.11.091.

[52] Ordorica-Garcia G., Douglas P., Croiset E. et al.. Technoeconomic evaluation of IGCC power plants for CO2 avoidance. Energy Convers Manage, 2006, 47, 2250-2259. Access: https://doi. org/10.1016/j.enconman.2005.11.020.

[53] Zanga G., Zhanga J., Jiab J., Lorac E.S., Ratner A. 2020. Life cycle assessment of powergeneration systems based on biomass integrated gasification combined cycles. Renewable Energy, 2020, 149, 336-346. Access: https://doi.org/10.1016/j.renene.2019.12.013.

[54] Ahmad F., Khaliq A., Idrees M. Energetic and Exergetic Analyses of Biomass Derived Syngas for Triple Cycle Power Generation. Distributed Generation \& Alternative Energy Journal, 2017, 32: 4, 26-53. Access: https://doi.org/10.1080/21563306.2017.11909734.

[55] Tana Y., Nookueab W., Lib H., Thorinb E., Yanab J. Property impacts on Carbon Capture and Storage (CCS) processes: A review. Energy Conversion and Management, 2016, 118, 204-222. Access: https://doi.org/10.1016/j.enconman.2016.03.079.

[56] Yan L., Wang Z., Cao Y., He B. Comparative evaluation of two biomass direct-fired power plants with carbon capture and sequestration. Renewable Energy, 2020, 147 (1), 1188-1198. Access: https://doi.org/10.1016/j.renene.2019.09.047.

[57] Garcia-Nunez J.A.M., Pelaez-Samaniego R. et al. Historical Developments of Pyrolysis Reactors: A Review. Energy Fuels, 2017, 31, 5751-5775.. DOI: 10.1021/acs.energyfuels.7b00641.

[58] SriBala G., Carstensen. H. et al. Measuring biomass fast pyrolysis kinetics: State of the art. WIREs Energy Environ. 2019. Access: https://doi.org/10.1002/wene.326.

$$
-403-
$$


[59] Guo M., Song W. et al. Bioenergy and biofuels: History, status, and perspective. Renewable and Sustainable Energy Reviews, 2015, 42, 712-725. Access: http://dx.doi.org/10.1016/j. rser.2014.10.013.

[60] Рохман Б.Б. Топка с циркулирующим кипящим слоем для сжигания антрацитового штыба и термоконтактный пиролиз угля. Теплоэнергетика, 2007, 9, 40-45 [Rohman B.B. Circulating fluidized bed furnace for anthracite rod combustion and thermal contact pyrolysis of coal. Thermal power engineering, 2007, 9, 40-45 (In Russian)].

[61] Yang Y., Brammer J.G. et al. Combined heat and power from the intermediate pyrolysis of biomass materials: performance, economics and environmental impact. Applied Energy, 2017, 191, 639-652. Access: http://dx.doi.org/10.1016/j.apenergy.2017.02.004.

[62] Patel A., Agrawal B. et al. Pyrolysis of biomass for efficient extraction of biofuel. Energy Sources. Part A: Recovery, Utilization, and Environmental Effects. Access: https://doi.org/10.1080/15 567036.2019.1604875.

[63] Liu X.C., Cui P. et al. A review on co-pyrolysis of coal and oil shale to produce coke. Frontiers of Chemical Science and Engineering, 2019. DOI: 10.1007/s11705-019-1850-z.

[64] Promdee K., Vitidsant T. Пиролиз биотоплива - императы цилиндрической - в реакторе с двухшнековым питателем. Теплоэнергетика, 2014, 8, 74-80 [Promdee K., Vitidsant T. Biofuel pyrolysis - cylinder emperors - in double screw feeder reactor. Thermal power engineering, 2014, 8, 74-80 (In Russian)].

[65] Ramosa A., Monteiro E. et al. Numerical approaches and comprehensive models for gasification process: A review. Renewable and Sustainable Energy Reviews. 2019, 110, 188-206. Access: https://doi.org/10.1016/j.rser.2019.04.048.

[66] Чирков В.Г. Мини-ТЭС на пиролизном топливе. Теплоэнергетика, 2007, 8, 35-39 [Chirkov V.G. Mini-TPP on pyrolysis fuel. Thermal power engineering, 2007, 8, 35-39 (In Russian)].

[67] Reddy B.R., Vinu R. Feedstock Characterization for Pyrolysis and Gasification. 2018. DOI: 10.1007/978-981-10-7335-9_1.

[68] Заворин А.С., Казаков А.В., Макеев А.А. Исследование процесса генерации газа в автономных энергетических установках. Теплотехника, 2010, 1, 74-78 [Zavorin A.C., Kazakov A.V., Makeev A.A. Study of gas generation process in autonomous power plants. Heat engineering, 2010, 1, 74-78. (In Russian)].

[69] Tabakaeva R., Kanipaa I., Astafeva A. et al. Thermal enrichment of different types of biomass by low-temperature pyrolysis. Fuel, 2019, 245, 29-38. Access: https://doi.org/10.1016/j. fuel.2019.02.049.

[70] Tabakaev R.B., Astafev A.V., Zavorin A.S. et al. Autothermal pyrolysis of biomass due to intrinsic thermal decomposition effects. Journal of Thermal Analysis and Calorimetry, 2018, 134 (2), 1045-1057.. DOI: 10.1007/s10973-018-7562-7.

[71] Tabakaev R., Shanenkov I., Kazakov A., Zavorin A. Thermal processing of biomass into highcalorific solid composite fuel. Journal of Analytical and Applied Pyrolysis, 2017, 12,. 94-102. DOI: 10.1016/j.jaap.2017.02.016.

[72] Tabakaev R., Astafev A., Shanenkova Yu. et al. Thermal effects investigation during biomass slow pyrolysis in a fixed bed reactor. Biomass and Bioenergy, 2019, 126, 26-33. DOI: 10.1016/j. biombioe.2019.05.010. 
[73] Zavorin, A.S., Dolgikh, A.Y., Salomatov, V.V. et al. Heat engineering characteristics of coals of the Shive-Ovoos field of Mongolia as power-plant fuel. Bull. Tomsk Polytechnic University, 2014, 324 (4), 47-53.

[74] Singh R. 2017. Principles and Applications of Environmental Biotechnology for a Sustainable Future. Springer-Verlag Singapore PTE LTD. Singapore. P. 487. DOI: 10.1007/978-981-10-1866-4.

[75] Patel A., Agrawal B., Rawal B.R. Pyrolysis of biomass for efficient extraction of biofuel. Energy Sources. 2019. Part A: Recovery, Utilization, and Environmental Effects. Access: https://doi.or g/10.1080/15567036.2019.1604875.

[76] Gupta G. K., Gupta P.K, Mondal M.K., Experimental process parameters optimization and in-depth product characterizations for teak sawdust pyrolysis. Waste Management, 2019, 87, 499511. DOI: 10.1016/j.wasman.2019.02.035.

[77] Palamanit A., Khongphakdi P., Tirawanichakul Y., Phusunti N. Investigation of yields and qualities of pyrolysis products obtained from oil palm biomass using an agitated bed pyrolysis reactor. Biofuel Research Journal, 2019, 6 (4), 1065-1079. DOI: 10.18331/BRJ2019.6.4.3.

[78] Saadi W., Rodríguez-Sanchez S., Ruiz B. et al. Pyrolysis technologies for pomegranate (Punica granatum L.) peel wastes. Prospects in the bioenergy sector. Renewable Energy, 2019, 136, 373-382. DOI: 10.1016/j.renene.2019.01.017.

[79] Jager N., Conti R. et al. Thermo-catalytic reforming of woody biomass. Energy Fuels, 2016, 30, 10. Access: https://doi.org/10.1021/acs.energyfuels.6b00911.

[80] Conti R., Jager N. et al. Thermocatalytic reforming of biomass waste streams. Energy Technol, 2017, 5 (1), 104-110. DOI: 10.1002/ente.201600168.

[81] Moreno V.C., Iervolino G. et al. Techno-economic and environmental sustainability of biomass waste conversion based on thermocatalytic reforming. Waste Management, 2020, 101, 106115. DOI: 10.1016/j.wasman.2019.10.002.

[82] Falyushin P.L., Zhuravskii G.I. et al. Qualitative characteristics of the fuel gas obtained as a result of the thermochemical processing of plant biomass by the pyrolysis method. Journal of Engineering Physics and Thermophysics, 2009, 82 (3), 442-447. DOI: 10.1007/s10891-009-0207-8.

[83] Gupta S., Gupta G., Mondal M. Slow pyrolysis of chemically treated walnut shell for valuable products: Effect of process parameters and in-depth product analysis. Energy, 2019, 181, 665-676. Access: https://doi.org/10.1016/j.energy.2019.05.214.

[84] Kongkasawan J., Nam H., Capareda S. Jatropha waste meal as an alternative energy source via pressurized pyrolysis: A study on temperature effects. Energy, 2016, 113, 631-642. Access: http:// dx.doi.org/10.1016/j.energy.2016.07.030.

[85] Capunitan J., Capareda S. Assessing the potential for biofuel production of corn stover pyrolysis using a pressurized batch reactor. Fuel, 2012, 95, 563-572. DOI:10.1016/j.fuel.2011.12.029.

[86] Nyakuma B., Oladokun O. Biofuel characterization and pyrolysis kinetics of Acacia mangium. Chemistry \& Chemical Technology, 2017, 11 (3), 392-396. Access: https://doi.org/10.23939/ chcht11.03.392. 